DIMENSI, VOL. 8, NO. $1: 187-197$

MARET 2019

ISSN: 2085-9996

\title{
Hubungan Antara Kecerdasan Linguistik Verbal Dan Kemampuan Membaca
}

\section{The Relationship Between Verbal Linguistic Intelligence And Reading Comprehension}

\author{
Desi Surlitasari Dewi ${ }^{1}$, Eka Wilany $^{2}$ \\ ${ }^{1}$ Prodi Pendidikan Bahasa Inggris, Universitas Riau Kepulauan, Indonesia \\ ${ }^{2}$ Prodi Pendidikan Bahasa Inggris, Universitas Riau Kepulauan, Indonesia \\ 'belldaisy46@gmail.com, ${ }^{2}$ ekawilany3@gmail.com
}

\begin{abstract}
Abstrak
Penelitian ini bertujuan untuk mengetahui apakah terdapat hubungan antara kecerdasan linguistik verbal dan kemampuan membaca teks L2 (Bahasa Inggris) pada mahasiswa Prodi Pendidikan Bahasa Inggris Universitas Riau Kepulauan. Penelitian ini merupakan penelitian kuantitafif dengan desain penelitian korelasi dimana terdapat dua variabel yaitu kecerdasan linguistik verbal sebagai variabel bebas dan kemampuan membaca teks L2 sebagai variabel terikat. Data penelitian didapatkan dengan menggunakan tes intelegensi verbal dan tes membaca (reading test). Sebelum dilaksanakan uji hipotesis, tes normalitas dilakukan untuk mengetahui apakah sebaran data dalam kategori normal atau tidak. Berdasarkan tes normalitas, diketahui bahwa $L_{\text {hitung }}=0.087$ yaitu lebih rendah dari $L_{\text {tabel }}=0,1269$, artinya data berdistribusi normal dan dapat dilakukan uji hipotesis. Uji hipotesis dilakukan dengan menggunakan Pearson Product Moment untuk mengetahui tingkat hubungan antara kedua variabel, dengan hasil sebagai berikut, $r_{\text {count }}=0,680$; dimana $r_{\text {hitung }}=0,235 n=48$ pada taraf signifikansi 5\%. Kemudian, $t$ test dilakukan untuk mengetahui apakah hubungan antara kedua variabel tersebut signifikan atau tidak. Adapun hasil dari t test adalah6.29 yaitu lebih tinggi dari $t_{\text {tabel }}=2.013$ Maka, dapat disimpulkan bahwa terdapat hubungan yang signifikan antara kecerdasan linguistik verbal dan kemampuan membaca teks L2.
\end{abstract}

Kata Kunci: Kecerdasan linguistik verbal, Kemampuan membaca, Teks L2

\begin{abstract}
This study aims to find out whether there is a relationship between Verbal Linguistic Intelligence and L2 Reading Comprehension of English Department Students of Universitas Riau Kepulauan. The design of the study is a correlational research and the variables are Verbal Linguistic Intelligence as independent variable, and L2 Reading Comprehension as dependant variable.Data were gathered from verbal linguistic intelligence and reading test. Before testing the hypothesis, normality test was conducted to find out if the data were in normal distribution. It is found out that Lcount $=0.087$ which is smaller than L table $=0.1269$, it means that the data were in normal distribution and hypothesis testing could be conducted by using Pearson Product Moment to see the relationship between verbal linguistic intelligence and L2 reading comprehension. Then, $t$ test was conducted to find out whether the correlation was significant or not. It was found out that $r$ count $=0.68$ is higher than $r$ table $=0.235, n=48$ level of significance $5 \%$. Then, it can be concluded that there was a significant correlation between verbal linguistic intelligence and reading comprehension.
\end{abstract}

Keywords: Verbal linguistic intelligence, Reading Comprehension, L2 Text 
DIMENSI, VOL. 8 , NO. $1: 176-185$

MARET 2019

ISSN: 2085-9996

\section{PENDAHULUAN}

Seperti yang kita ketahui, kecerdasan dapat menjadi salah satu faktor dalam penentu keberhasilan pembelajaran bahasa asing. Meskipun terdapat faktor-faktor lain yang tidak kalah penting selain kecerdasan, namun tetap perlu dilaksanakan kegiatan belajar mengajar yang mendukung siswa untuk dapat memanfaatkan kecerdasan mereka secara aktif. Mengetahui tingkat kecerdasan siswa tentunya akan efektif untuk menentukan arah pengajaran dan membuat siswa sadar akan kelemahan dan kekuatan mereka. Selain itu, melibatkan siswa untuk aktif dalam proses belajar dapat membuat mereka bertanggung jawab atas sejauh mana keberhasilan pembelajaran merekaSalah satu kemampuan yang sering menjadi tolok ukur dalam pengukuran kemampuan bahasa asing adalah kemampuan membaca atau pemahaman membaca.

\section{Pemahaman Membaca Teks L2}

Membaca merupakan sebuah proses dimana pembaca menggabungkan informasi dari sebuah teks dan latar belakang pengetahuan mereka untuk mengkonstruksi pesan atau arti dari teks.Sementara itu, Patel dan Jain (2008: 113) menyebutkan bahwa membaca adalah memahami arti dari kata-kata atau simbol yang tertulis. Membaca merupakan proses identifikasi dan mengenali simbol tertulis yang berperan sebagai stimulus untuk mendapatkan makna yang diperoleh dari latar belakang pengetahuan. Membaca memiliki fungsi yang sangat krusial bagi dunia ilmu pengetahuan, karena peran pentingnya dalam mendapatkan pengatehuan dan memperluas cara berpikir manusia.

Membaca tidak dapat dipisahkan dengan pemahaman, karena pemahaman merupakan bagian yang paling penting dari kegiatan membaca. Snow (2002) dalam Ranjbar dan Akef (2015) menyebutkan bahwa pemahaman membaca merupakan proses mengekstraksi dan mebentuk makna secara bersamaan melalui interaksi dan keterlibatan dengan simbol tertulis atau teks. Proses ini melibatkan tiga elemen yaitu pembaca, teks bacaan, dan tujuan membaca. Dalam memahami bacaan, pembaca berusaha mendapatkan makna melalui motivasi membaca, latar belakang pengetahuan, kemampuan kognitif, dan pengalaman membaca. Hal-hal tersebut dapat membantu proses membaca menjadi lebih efektif. 
Pang et al. (2003:14) dalamRanjbar and Akef (2015:55) menyatakan bahwa pemahaman bukanlah sebuah proses yang pasif, melainkan sebuah proses aktif dalam membentuk makna di dalam pikiran kita. Untuk dapat memahami bacaan, pembaca perlu terlibat dan terhubung dengan teks secara aktif dengan menggunakan latar belakang pengetahuan untuk membentuk suatu pemikiran logis dan masuk akal.

Penilaian dalam membaca dapat dilakukan dengan sebuah reading test. Dalam penilaian pemahaman membaca, tes lebih terfokus pada kemampuan mendapatkan topik dan ide pokok bacaan daripada detail-detail kecil. Aspek tersebut merupakan kemampuan berpikir kritis dibandingkan menemukan detail-detail kecil dalam bacaan. Tes-tes membaca dapat berbentuk multiple choice, jawaban pendek, atau jawaban panjang. Indikator dari tes membaca harus terkait dengan tujuan penilaian dan definisi pemahaman membaca itu sendiri. Dalam penelitian ini, indikator dari tes membaca meliputi:

1) Menemukan ide pokok bacaan

2) Memahami ungkapan-ungkapan atau frase-frase dalam bacaan

3) Memahami makna dari pesan yang tersirat dalam bacaan

4) Menemukan detail-detail informasi dalam bacaan

5) Mengklasifikasikan ide pendukung dalam bacaan

6) Menemukan arti kata-kata dalam konteks bacaan

\section{Kecerdasan Linguistik Verbal}

Sementara itu, kecerdasan adalah kemampuan untuk memecahkan masalah atau menghasilkan sesuatu yang bernilai dalam kultur. Kecerdasan merupakan bawaan dari seseorang ketika dilahirkan. Davoudi dan Chavos (2016: 202) menyatakan bahwa kecerdasan adalah gagasan psikologis yang berhubungan dengan pembelajaran yang mendasari banyak keputusan profesional para pendidik.

Secara spesifik, kecerdasan digolongkan menjadi delapan jenis, yaitu: kecerdasan berbahasa, kecerdasan logis matematis, kecerdasan spasial, kecerdasan kinestetik atau gerak, kecerdasan interpersonal, kecerdasan intrapersonal, kecerdasan visual, dan kecerdasan naturalistik (Gardner dalam Sistani dan Hashemian (2016: 243).Menurut Gardner 1983, 1999, 2004, dalam Madkour \&Mohamed (2016: 92), teori kecerdasan majemuk merupakan 
pengakuan penting tentang keragaman cara yang didekati peserta didik, ini membantu guru dan peserta didik untuk berhasil dalam pengajaran. Teori ini mengemukakan gagasan bahwa individu mampu belajar melalui berbagai kecerdasan yang berbeda.

Salah satu jenis kecerdasan yang berpengaruh dalam pembelajaran bahasa adalah kecerdasan verbal linguistik. Jenis kecerdasan tersebut merupakan kecerdasan untuk memahami struktur, bunyi, dan makna bahasa (Armstrong, 2009: 6). Sementara itu,Ihsan (2017: 42) menyatakan bahwa kecerdasan Linguistik Verbal adalah Kecerdasan yang terkait dengan kemampuan menunjukkan kemampuan memahami komunikasi dan informasi dari lawan bicara, baik dalam bentuk lisan maupun dalam bentuk tertulis.

Kecerdasan verbal-linguistik telah diakui bertahun-tahun sebelum kehadiran kecerdasan lain. Kecerdasan verbal-linguistik dan kecerdasan logis-matematis digunakan sebagai pengukuran IQ. Kedua kecerdasan telah menjadi tes standar di beberapa akademis seperti Penilaian Nasional Program Pendidikan (NAEP), Tes Iowa Keterampilan Dasar (ITBS), dll. Selain itu, Alfred Binet membuat tes IQ untuk mengukur kecerdasan anak-anak sekolah dasar di Perancis. Kemudian, Angkatan Bersenjata AS mulai menggunakan tes dalam Perang Dunia I. Pada dasarnya, Tes Binet hanya mengukur dua kecerdasan: kecerdasan verbal - linguistik dan logika - kecerdasan matematika. Jadi, dapat disimpulkan bahwa kecerdasan tersebut digunakan sebagai fokus utama kecerdasan.

Selanjutnya, kecerdasan linguistik verbal yang tinggi dapat dilihat dari berbagai macam indikator di bawah ini:

a. Mampu menulis pengalaman sehari-hari

b. Mampu mengemukakan idenya secara jelas

c. Mengetahui banyak kosakata dan mampu menggunakannya dengan tepat

d. Suka membaca berbagai macam jenis teks seperti buku, koran, majalah, dan bacaan apapun. Mampu memberikan pendapat terhadap bahan bacaan.

e. Mampu mengeja dalam bahasa asing dan mudah mempelajari kata-kata baru

f. Menyukai menyimak cerita, review radio, bahkan kata-kata yang sulit diucapkan

g. Mampu berbicara dalam jangka waktu yang lama dan mendongeng atau bercerita 


\section{METODE PENELITIAN}

Penelitian ini merupakan penelitian kuantitatif dengan menggunakan desain korelasi yang bertujuan untuk mengetahui apakah ada hubungan antara variabel x yaitu kecerdasan linguistik verbal dan variabel y yaitu kemampuan pemahaman membaca. Populasi dari penelitian ini yaitu seluruh mahasiswa Prodi Pendidikan Bahasa Inggris yang berjumlah 240 orang. Dari jumlah populasi tersebut, diambil sampel sebanyak 20\% dengan menggunakan teknik simple random sampling, maka didapatkan sampel sejumlah 48 responden yang dipilih secara acak dari populasi. (Arikunto, 2012: 112)

Selanjutnya, data diperoleh dengan menggunakan dua instrumen, yaitu tes membaca (reading test) untuk mendapatkan data kemampuan pemahaman membaca responden (variabel y) dan angket kecerdasan linguistik verbal untuk mengetahui tingkat kecerdasan linguistik verbal responden. Sebelum digunakan untuk pengambilan data, kedua instrumen tersebut diujikan validitas dan reliabilitasnya untuk mendapatkan alat uji yang valid dan sahih. Untuk menguji validitas angket, dilakukan uji validitas dengan menggunakan biserial point dan alpha cronbach untuk menguji reliabilitas kuesioner. Sedangkan untuk menguji validitas tes membaca, dilakukan uji validitas dengan menggunakan pearson product moment dan kr-20 untuk menguji reliabilitas tes.

Sebelum uji hipotesis dilakukan, terlebih dahulu dilakukan uji normalitas untuk memastikan bahwa data berdistribusi normal sehingga statistik parametrik dapat diterapkan. Selanjutnya, untuk mengetahui koefisien korelasi dari kemampuan pemahaman membaca dan kecerdasan linguistik verbal, dilakukan uji korelasi dengan menggunakan pearson product moment correlation. Hasil koefisien korelasi tersebut, kemudian diuji dengan menggunakan $\mathrm{t}$ test untuk mengetahui signifikansi korelasi dari kedua variabel.

\section{PEMBAHASAN}

Sebelum digunakan untuk pengambilan data, dilakukan uji validitas dan reliabilitas terhadap angket dengan hasil sebagai berikut:

a. Uji Validitas Test

Uji validitas tes dilakukan dengan menggunakan uji product moment correlation yang diujicobakan terhadap 27 responden dengan hasil sebagai berikut: 
Tabel 1 Hasil Uji Validitas Tes

\begin{tabular}{|c|c|c|c|}
\hline No. Item & $\mathrm{R}$ hitung & R tabel & Valid/Tidak \\
\hline 1 & 0.340 & 0.312 & Valid \\
\hline 2 & 0.322 & 0.312 & Valid \\
\hline 3 & 0.456 & 0.312 & Valid \\
\hline 4 & 0.520 & 0.312 & Valid \\
\hline 5 & 0.423 & 0.312 & Valid \\
\hline 6 & 0.488 & 0.312 & Valid \\
\hline 7 & 0.320 & 0.312 & Valid \\
\hline 8 & 0.512 & 0.312 & Valid \\
\hline 9 & 0.316 & 0.312 & Valid \\
\hline 10 & 0.288 & 0.312 & Tidak \\
\hline 11 & 0.354 & 0.312 & Valid \\
\hline 12 & 0.520 & 0.312 & Valid \\
\hline 13 & 0.317 & 0.312 & Tidak \\
\hline 14 & 0.340 & 0.312 & Valid \\
\hline 15 & 0.444 & 0.312 & Valid \\
\hline 16 & 0.535 & 0.312 & Valid \\
\hline 17 & 0.410 & 0.312 & Valid \\
\hline 18 & 0.512 & 0.312 & Valid \\
\hline 19 & 0.366 & 0.312 & Valid \\
\hline 20 & 0.356 & 0.312 & Valid \\
\hline 21 & 0.332 & 0.312 & Valid \\
\hline 22 & 0.310 & 0.312 & Tidak \\
\hline 23 & 0.266 & 0.312 & Tidak \\
\hline 24 & 0.356 & 0.312 & Valid \\
\hline 25 & 0.510 & 0.312 & Valid \\
\hline 26 & 0.375 & 0.312 & Valid \\
\hline 27 & 0.320 & 0.312 & Valid \\
\hline 28 & 0.394 & 0.312 & Valid \\
\hline 29 & 0.4 & 0.312 & Valid \\
\hline 30 & 0.358 & 0.312 & Valid \\
\hline
\end{tabular}

Dari tabel diatas, diketahui bahwa terdapat 26 item tes yang valid dan terdapat 4 item tes yang invalid. Untuk praktikalitas instrumen, maka diambil secara acak 25 test item dari 26 item tes yang valid tersebut.

b. Uji Reliabilitas Tes

Setelah menentukan 25 item yang valid, maka dilakukan uji reliabilitas instrumen dengan menggunakan KR-20 dengan hasil sebagai berikut: 
Tabel 2 Uji Reliabilitas Tes

\begin{tabular}{llrlll}
\hline $\mathbf{K}$ & $\mathbf{M}$ & $\boldsymbol{S}_{\boldsymbol{t}}$ & $\mathbf{r}_{\text {counted }}$ & $\mathbf{r}_{\text {table }}$ & Status \\
\hline $\mathbf{2 4}$ & $\mathbf{1 7 , 3 3}$ & 18,15 & 0.77 & 0.7 & Reliable \\
\hline
\end{tabular}

Dari tabel diatas, diketahui bahwa $\mathrm{r}$ hitung lebih tinggi dari $\mathrm{r}$ tabel, maka dapat disimpulkan bahwa instrumen tersebut reliabel.

c. Uji Validitas Kuesioner

Uji validitas tes dilakukan dengan menggunakan uji product moment correlation dengan hasil sebagai berikut:

Tabel 3 Hasil Uji Validitas Kuesioner

\begin{tabular}{cccc}
\hline No. Item & R hitung & $\begin{array}{c}\mathrm{R} \\
\text { tabel }\end{array}$ & Valid/Tidak \\
\hline 1 & 0.396 & 0.380 & Valid \\
2 & 0.412 & 0.380 & Valid \\
3 & 0.448 & 0.380 & Valid \\
4 & 0.412 & 0.380 & Valid \\
5 & 0.56 & 0.380 & Valid \\
6 & 0.396 & 0.380 & Valid \\
7 & 0.381 & 0.380 & Valid \\
8 & 0.510 & 0.380 & Valid \\
9 & 0.388 & 0.380 & Valid \\
10 & 0.386 & 0.380 & Valid \\
11 & 0.410 & 0.380 & Valid \\
12 & 0.448 & 0.380 & Valid \\
13 & 0.384 & 0.380 & Valid \\
14 & 0.494 & 0.380 & Valid \\
15 & 0.483 & 0.380 & Valid \\
16 & 0.399 & 0.380 & Valid \\
17 & 0.390 & 0.380 & Valid \\
18 & 0.430 & 0.380 & Valid \\
19 & 0.449 & 0.380 & Valid \\
20 & 0.506 & 0.380 & Valid \\
\hline
\end{tabular}


Dari hasil uji validitas angkettersebut, terlihat bahwa seluruh item memiliki r hitung yang lebih tinggi dari $\mathrm{r}$ tabel. Maka dapat disimpulkan bahwa seluruh item tersebut valid.

d. Uji Reliabilitas Kuesioner

Setelah menentukan item yang valid, maka dilakukan uji reliabilitas instrumen dengan menggunakan Alpha Cronbach dengan hasil sebagai berikut:

Tabel 4 Uji Reliabilitas Angket

\begin{tabular}{cccccc}
\hline $\mathbf{K}$ & $\boldsymbol{\Sigma} \boldsymbol{\sigma}_{\boldsymbol{i}}^{\mathbf{2}}$ & $\boldsymbol{\sigma}_{\boldsymbol{t}}$ & $\mathbf{r}_{\text {counted }}$ & $\mathbf{r}_{\text {table }}$ & Status \\
\hline $\mathbf{2 2}$ & 25.03 & 136.4 & 0.856 & 0.6 & Reliable \\
\hline
\end{tabular}

Berdasarkan perhitungan pada tabel diatas, dapat diketahui bahwa $\mathrm{r}$ hitung lebih tinggi dari r tabel, maka dapat disimpulkan bahwa kuesioner tersebut reliabel.

e. Uji normalitas

Sebagai prasyarat dilakukannya uji statistik parametrik, perlu dilakukan uji normalitas untuk mengetahui apakah data yang didapatkan memiliki distribusi normal. Untuk itu, digunakan Liliefors untuk menentukan apakah data berdistribusi normal atau tidak. Adapun hasil dari uji Liliefors adalah sebagai berikut:

\section{Tabel 5 Uji Normalitas Data}

\begin{tabular}{ccc}
\hline L hitung & L tabel & Hasil \\
\hline 0.087 & $\mathbf{0 . 1 2 6 9}$ & Berdistribusi Normal \\
\hline
\end{tabular}

Dari tabel diatas, dapat disimpulkan bahwa data memiliki distribusi normal. Maka selanjutnya, dapat dilakukan uji korelasi dengan menggunakan pearson product moment.

f. Uji korelasi

Setelah diketahui bahwa berdistribusi normal, selanjutnya dapat dilakukan uji korelasi dengan menggunakan pearson product moment untuk mengetahui koefisien korelasi dari kecerdasan linguistik verbal dan kemampuan pemahaman membaca dengan hasil sebagai berikut: 
Tabel 6 Uji Korelasi

\begin{tabular}{ccc}
\hline R hitung & R tabel & Hasil \\
\hline $\mathbf{0 . 6 8 0}$ & 0.235 & Korelasi Positif \\
& & Koefisien Tinggi \\
\hline
\end{tabular}

Dari uji korelasi diatas, dapat disimpulkan bahwa terdapat korelasi yang positif antara kecerdasan linguistik verbal dan kemampuan pemahaman membaca teks berbahasa Inggris. Artinya, kecerdasan linguistik verbal yang lebih tinggi kemungkinan akan diikuti oleh pemahaman membaca yang lebih tinggi juga. Demikian pula sebaliknya, kecerdasan linguistik verbal yang lebih rendah maka akan cenderung memiliki pemahaman membaca yang lebih rendah. Adapun koefisien korelasi yaitu 0.680 maka termasuk pada kategori tinggi.

g. Uji signifikansi

Untuk mengetahui apakah korelasi antara kedua variabel signifikan atau tidak, selanjutnya dilakukan uji $\mathrm{t}$ dengan hasil sebagai berikut

\section{Tabel 7 Uji Signifikansi}

\begin{tabular}{ccc}
\hline t hitung & t tabel & Hasil \\
\hline $\mathbf{6 . 2 9}$ & 2.013 & Signifikan \\
& & \\
\hline
\end{tabular}

Dari hasil analisis diketahui bahwa terdapat korelasi yang positif antara kecerdasan linguistik verbal dan kemampuan pemahaman membaca bahasa asing, artinya siswa dengan tingkat kecerdasan linguistik verbal yang tinggi cenderung memiliki kemampuan pemahaman membaca yang lebih tinggi. Sementara itu, siswadengan tingkat kecerdasan linguistik verbal rendah memiliki kemampuan memahami bacaan lebih rendah dibanding siswa yang memiliki tingkat kecerdasan linguistik verbal tinggi. Dari hasil t test, diketahui bahwa hubungan yang 
dimiliki kedua variabel tersebut signifikan, artinya kecerdasan linguistik verbal memiliki hubungan yang kuat terhadap kemampuan pemahaman membaca bahasa asing.

\section{KESIMPULAN}

Berdasarkan pembahasan diatas, dapat disimpulkan bahwa kecerdasan linguistik verbal memiliki hubungan yang positif dan signifikan dengan kemampuan pemahaman membaca. Maka, selanjutnya perlu digali mengenai metode pembelajaran yang tepat dan strategi-strategi yang sesuai dengan karakteristik dan tingkat kecerdasan linguistik verbal siswa untuk mendapatkan hasil pembelajaran membaca teks bahasa asing yang optimal.

\section{REFERENSI}

Arikunto, Suharsimi. (2012). Prosedur Penelitian Suatu Pendekatan Praktek. Jakarta: RinekaCipta.

Armstrong, T. (2009). Multiple Intelligences. ( $3^{\text {rd }}$ Edition). Virginia, USA: Julie Houtz

Davoudi, M. \& Chavos, M. (2016).The relationship between Multiple Intelligences and Self Efficacy among Iranian EFL Learners. English Language Teaching, Vol 9,199.doi: 10.5539/eltv9n6p199

Ihsan, H. N. (2017). The Actualization of Literary Learning Model Based on Verbal - Linguistic Intelligence. International Journal of Education\& Literary Studies, Vol.5.ISSN : 2202-9478

Madkour, M. \& Mohamed, R.A.A.M. (2016). Identifying College Students' MultipleIntelligences to Enchase Motivation and Language Proficiency. English Language Teaching, Vol 9,93. doi: 10.5539/elt.v9n6p92

Patel. and M. F. Praveen M. Jain. (2008). English Language Teaching; Methods, Tools, and Technique. Jaipur: Sunrise Publishers Distributors.

Ranjbar, M Kherad and Akef, Kourosh. (2015). The Comparative Impact of Reading Comprehension and Translation Practices on EFL Learners' Grammar Achievement. Journal of Studies in Education, Vol. 5, No. 4, pp. 51-73. 
DIMENSI, VOL. 8, NO. $1: 187-197$

MARET 2019

ISSN: 2085-9996

Sistani, M. \& Hashemian, M. (2016). Investigating the Role of Multiple Intelligences in Determining Vocabulary Learning Strategie for L2 Learners. English Language Teaching, Vol 9, 242-243. doi: 10.5539/elt.v9n6p242. 